\title{
AMAZONAS THEATER ARCHITECTURAL CONSTRUCTION AND RESTORATIONS HISTORY
}

\author{
MARIA S. M. SAMPAIO \\ Escola Superior de Tecnologia (EST) \\ Universidade do Estado do Amazonas (UEA) \\ Darcy Vargas Avenue, 1.200 - Parque Dez de Novembro, 69050-020, Manaus/Amazonas - Brazil \\ e-mail:msampaio@uea.edu.br; socorrosampaio@hotmail.com
}

Keywords: Amazonas Theater, Historical Structure, Construction History, Restoration

\begin{abstract}
Built in the artistic splendor that prevailed in the late 19th century, Amazonas Theater is considered the most significant architectural construction of the so-called golden age of rubber, both for the values applied in its construction and for the symbolic importance it assumed, that is, the man's victory over the jungle, financial prosperity and the alleged artistic-cultural effervescence. However, when compared to the millenary constructions of the Ancient World, Amazonas Theater can be considered a "baby" and therefore a source of knowledge to be explored. In this sense, this paper intends to be the first one of a series of other ones that intends to study the behaviour of this structure. The paper is focused on describe the history of the construction of the Amazonas Theater highlighting the structural solution adopted to overcome the logistical challenges faced by a construction carried out in the middle of the largest tropical forest in the world and the main interventions performed during its 123 years. To this end, the building records of the Theater, an indispensable documentary source of the building's history, were consulted.
\end{abstract}

\section{INTRODUCTION}

Located in the middle of the Amazon forest in Manaus, Amazonas capital city, Brazil, the Amazonas Theater (Figure 1) took 17 years to be built from its conception until its opening in December 31, 1896. A place that would be frequented by the elite of belle époque, as it was called the period in which Manaus lived the golden age of rubber, Amazonas Theater became a symbol of a period of prosperity.
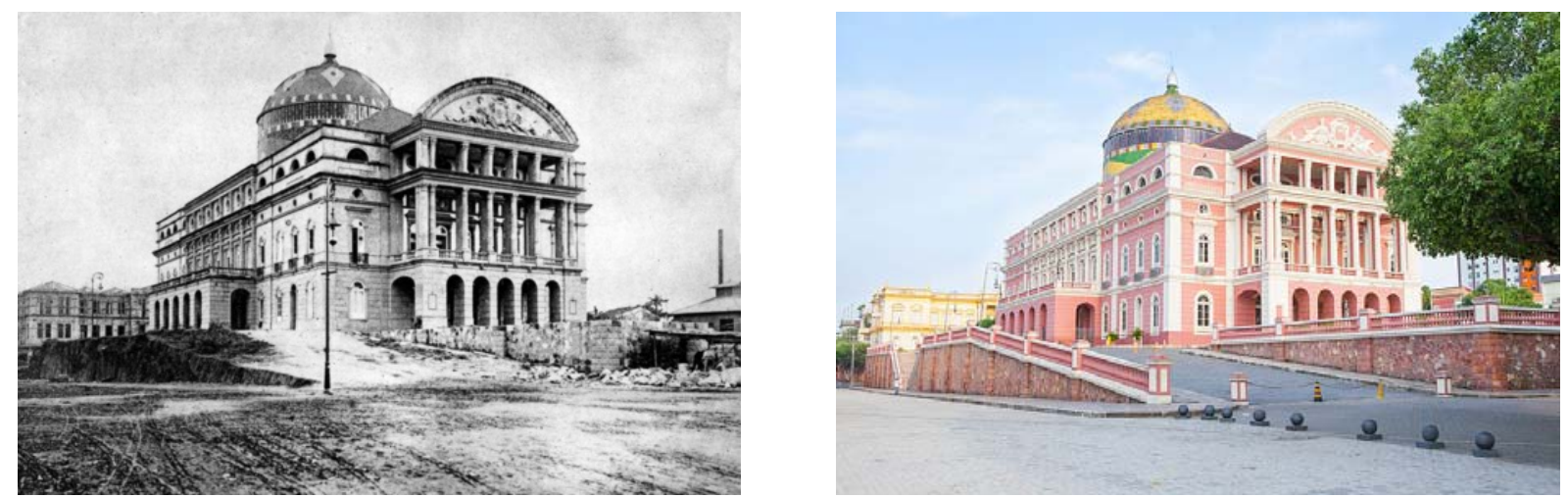

Figure 1: a) Amazonas Theater in construction [1,2]; b) Amazonas Theater in 2019. 
For its construction, not only architects, builders, painters, decorator and sculptors were brought from Europe, but also various materials such as Carrara marbles, Murano chandeliers, pieces of worked iron from England and French tiles. In the internal structure, the steel dome was manufactured in Belgium by the "Compagnie Centrale de Construction Haine-SaintPierre". The dome roof is composed of 36 thousand pieces of enamelled ceramic pottery and glazed tiles, coming from Alsace. The original coloring in green, blue and yellow is an analogy to the Brazilian flag.

It is important to mention that due to the difficulty of importing noble materials, some colonnades, straighteners, glasses and balusters were made of cement, masonry and plaster, but prepared to look like marble and other noble materials. Besides that, its construction caused controversy, as the city had only one hundred thousand inhabitants.

Throughout its history, the theater underwent four major structural interventions, being the last two real restorations. The four interventions took place, respectively, from 1926 until 1929 , from 1959 until 1962, from 1972 until 1974 and finally, from 1987 until 1990.

In 1966, on the occasion of its 70th birthday, the building was listed by the National Historical and Artistic Heritage Institute (IPHAN) being the first monument registered in Manaus by the Historical Patrimony.

\section{A BRIEF HISTORICAL CONSTRUCTION CHRONOLOGY}
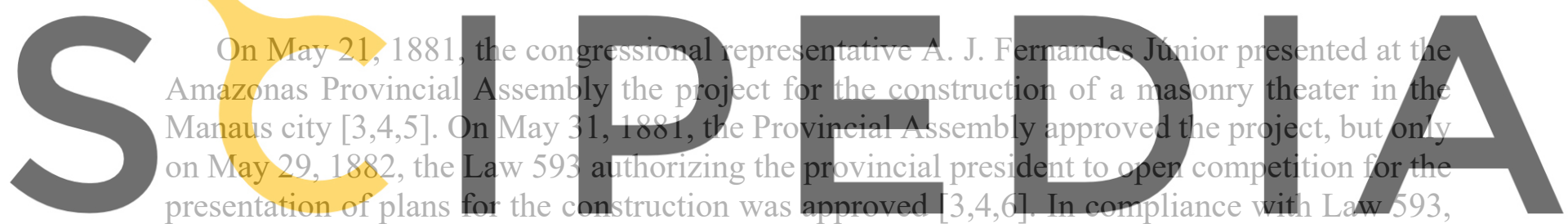

the provincial president José Paranaguá declared open competition for the presentation of plans,

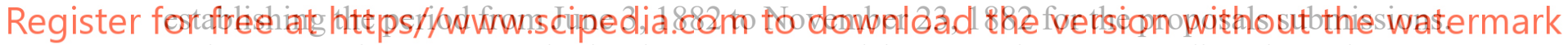
Only two projects were submitted: one presented by C. Celeste Saccardi and another one presented by the merchant Bernardo Antônio de Oliveira Braga. The project presented by Bernardo Braga and signed by the Portuguese Office of Engineering and Architecture of Lisbon (Figure 2) was chosen by the jury composed of the engineers Joaquim Leovilgido de Souza Coelho, João Carlos Antony, Charles B. Brisbin and the master builders José Pires dos Santos and Ismael Vitório Gomes [3,4,7]. On January 13, 1883, the Provincial Assembly accepted the plans chosen by the jury and ordered competition for the construction of the theater $[3,4,7]$. On January 17, 1883, the provincial treasury was authorized to open competition for the construction of the theater, and on May 17, 1883, four proposals were submitted. The proposal presented by the Manuel de Oliveira Palmeira de Meneses was approved and the contract was signed on August 23, $1883[3,4,8]$. Later the contract was transferred to the Italian company Rossi \& Irmãos [3,4,9]. Although the construction contract was signed on August 23, 1883 until December 31,1883 , the works had not been started because the earthwork was not properly prepared. In the following year, the earthworks began and finally on February 14, 1884 the foundation stone of the building was laid $[3,4,9]$. In September 1885, President Ferreira Júnior reported that in that year the theater had not progressed, but announced that in April 1885, almost all the iron material needed for the construction of the building arrived on a British 
steamer $[3,4,10]$. In February 1886, the director of the Public Works Bureau reported that in August of the previous year the president had the works suspended $[3,4,11]$. The construction contract with Rossi \& Irmãos was terminated on January 12, 1886 [3,4,11]. Construction was only restarted in 1893 by Governor Eduardo Gonçalves Ribeiro. In May 1893, Manuel Coelho de Castro signed a contract to restart the works. Eduardo Gonçalves Ribeiro hires the Brazilian artist Crispim do Amaral for the decoration, painting, ornamentation and furniture works of the Theater. Despite all the dedication of Eduardo Gonçalves Ribeiro, it was not possible to complete the work during his administration and still unfinished, Amazonas Theater was opened on December 31, 1896 [3,4,12,13,14]. In March 1897, Governor Fileto Pires Ferreira stated in his first message that despite all efforts, it was not possible to inaugurate the theater in the desired conditions. The work was not completed. The back facade, the balconies, the platform around the building and some internal work, including the decoration of the Noble Hall, were still missing [3,4,15]. In 1897, the Governor Fileto Pires Ferreira hired the Italian painter Domenico de Angelis to decorate the Noble Hall of the Amazonas Theater, which was opened only on the probable date of June 24, $1901[3,4]$.

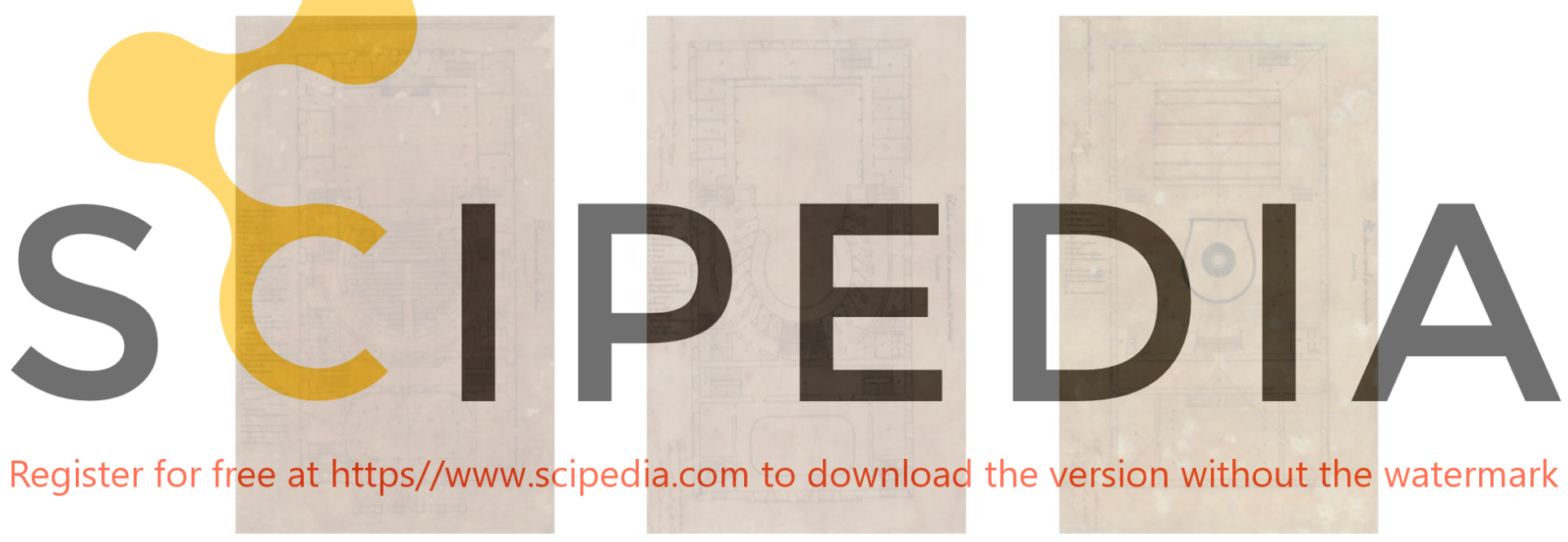

Figure 2: Original drawing of the Portuguese Office of Engineering and Architecture of Lisbon [16]: a) Ground floor plan [16]; b) 3th floor plan [16]; c) Attic plan [16].

\section{STRUCTURE AND CONSTRUCTION DETAILS OF AMAZONAS THEATER}

When researched about the structural solutions and construction details of the Amazonas Theater, it can be easily seen that Amazonas Theater have a very simple patterns, including a simple dome above, and a very common roof solutions. The construction structure of the theater is quite conventional, adopting the traditional four-walled box format (Figure 3a).

The monumentality of the building, with the overlapping of floors, required the use of much iron material, especially the large structures, which embrace the building and are hidden under the masonry. The presence of the iron elements in the construction of the theater is not so evident, but are revealed in the attic of the building, as well as in the roof and dome structures. The structural solution of the whole building in terms of the load transferring structure, start from the top of the dome to the end of the columns and the perimeter masonry, supported with iron bar in between columns, to the earth level. 
Although, externally, the Amazonas Theater presents renaissance composures, the diversity of materials and the variation of stylistic trends applied to the building facade and the different stylistic treatments adopted in the various environments defined the Amazon Theater as an eclectic architectural building.
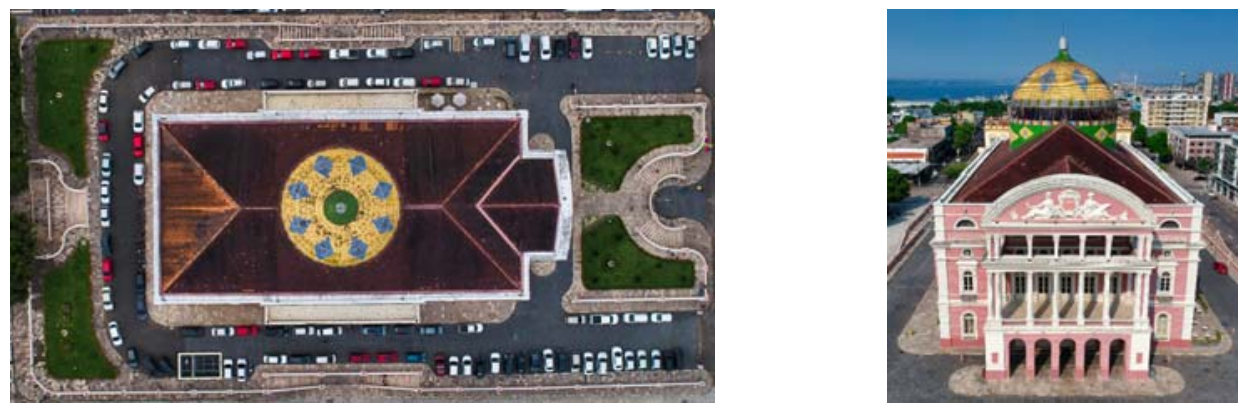

Figure 3: Amazonas Theater: a) Upper View; b) Frontal facade. Photo by Ivo Brasil Filho on June 4, 2019 [171

\subsection{The facade}

The facade is divided into three bodies, the prominent central body consisting of a frame that, on the ground floor, has five arches supported by pillars. On the second floor of this frame, there is a balcony surrounded by balustrades interrupted by the bases of the eight Corinthian columns that camouflage the pillars and support the entablature; above it stands another set of pillars that support the base of the pediment, these pillars being disguised by eight small pillars with capitals decorated which in its tympanun to music and theater, 3.2 The plans
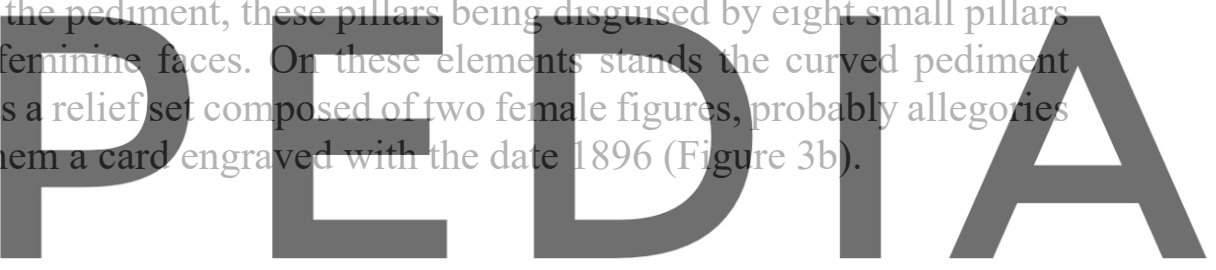

The Amazonas Theater has a ground floor, three floors and the Attic floor (Figure 4), being

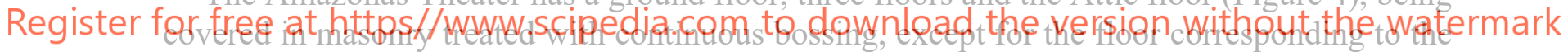
Attic floor. The mains environments on the ground floor are the Foyer and the Concert Hall. The Nobie Hall is located on the first floor. In the ground floor, the audience has 266 armchairs and 93 chairs distributed in 20 trimmings.
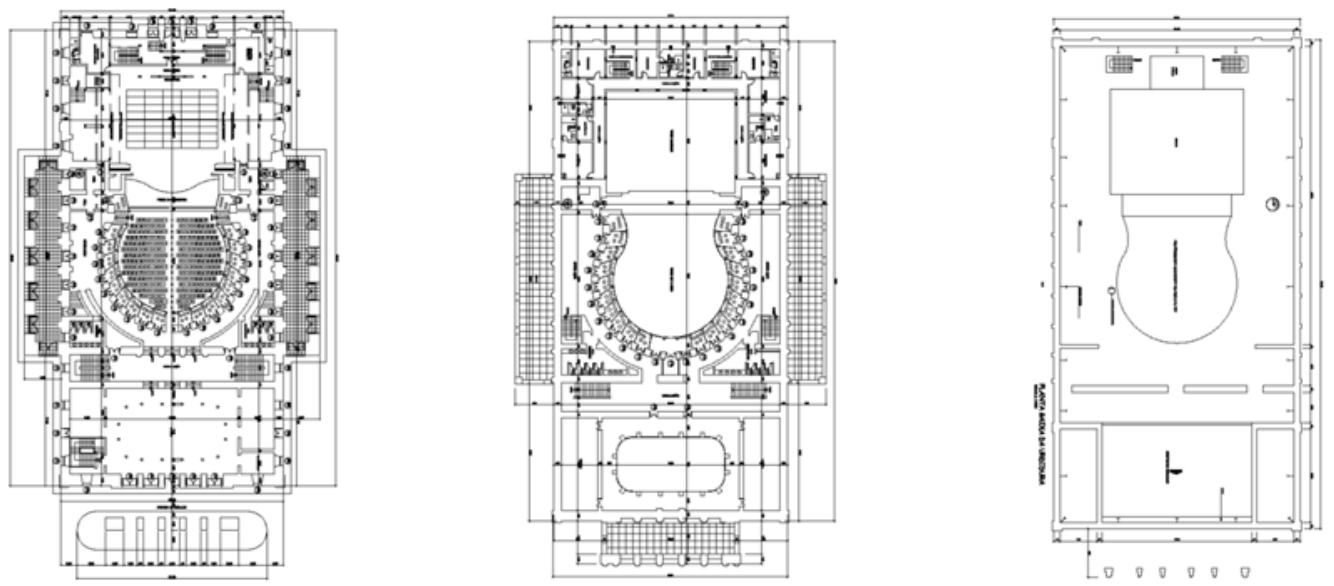

Figure 4: The plans of Amazonas Theater after renovation of 1972-1974: a) Ground floor plan; b) 3th floor plan; c) Attic plan. Filed in the Amazonas Theater Museum [18]. 
The 1st floor has 110 chairs distributed in 22 staterooms and the Governor's cabin. The 2nd floor has 125 chairs distributed in 25 cabins and finally, the 3rd floor has 95 chairs distributed in 19 staterooms. In according to the architectural ground plan, the Amazonas Theater has a plan with around $60.80 \mathrm{~m} \times 30.80 \mathrm{~m}$ and a height of 35 meters considering the dome.

\subsection{The Dome}

In the internal structure, the steel dome (Figure 5) was manufactured in Belgium by the "Compagnie Centrale de Construction Haine-Saint-Pierre". The dome roof is composed of 36 thousand pieces of enamelled ceramic pottery and glazed tiles, coming from Alsace. The original coloring in green, blue and yellow is an analogy to the Brazilian flag (Figure 5f).

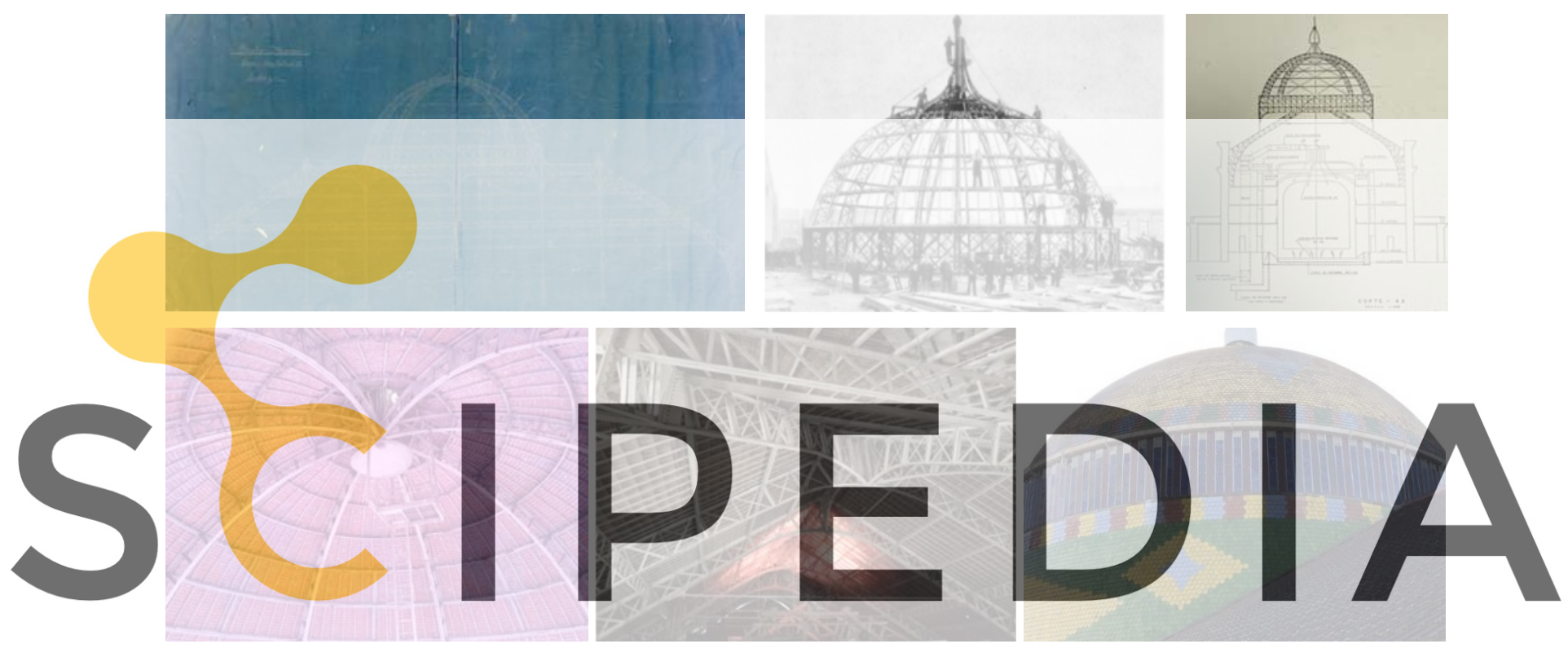

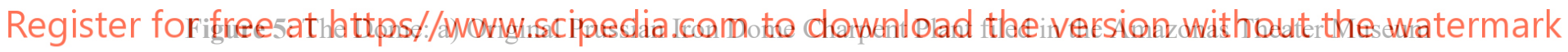

[18]; b) The iron dome in 1885 [18]; c) In section dome plan [19]; d) The iron dome in 2019; e) The iron roof in 2019; f) The dome roof in 2019.

In according to the architectural plan, the dome has a diameter of around 19 meters. The iron dome is composed of 8 curved flat trusses of variable height. In according to historical records $[12,13,14]$, the metallic structure of the roof and the dome took two years to assemble.

\subsection{Foyer, Concert Hall and Noble Hall}

The Foyer has 16 iron columns from Glasgow lined with concrete supported by pedestals lined in marble (Figure 6a).

The Concert Hall has a floor plan in the shape of a lyre or horseshoe. Around this hall there are three floors of cabins or friezes. Between the friezes on the ground floor there are columns of the Ionian order. These concrete-coated iron columns extend to the third floor, the capitals are of the Corinthian order. There are a total of 22 iron columns from Glasgow (Figura $6 \mathrm{~b}$ ). The decoration of the Concert Hall is by Crispim do Amaral. The ceiling of the Amazonas Theater concert hall consists of a barrel vault, an arched roof, built in wood pieces that lean into each other, in order to support their own weight and external loads. The wood used are blonde lead 
wood and black wood called "envira". The barrel vault structure, all made of interlaced wood, forming a kind of the shell which is supported by a intricate system of levers and wood beams, attached to rods, to resist efforts, forces or stress, fixed to the iron frame of the ceiling.
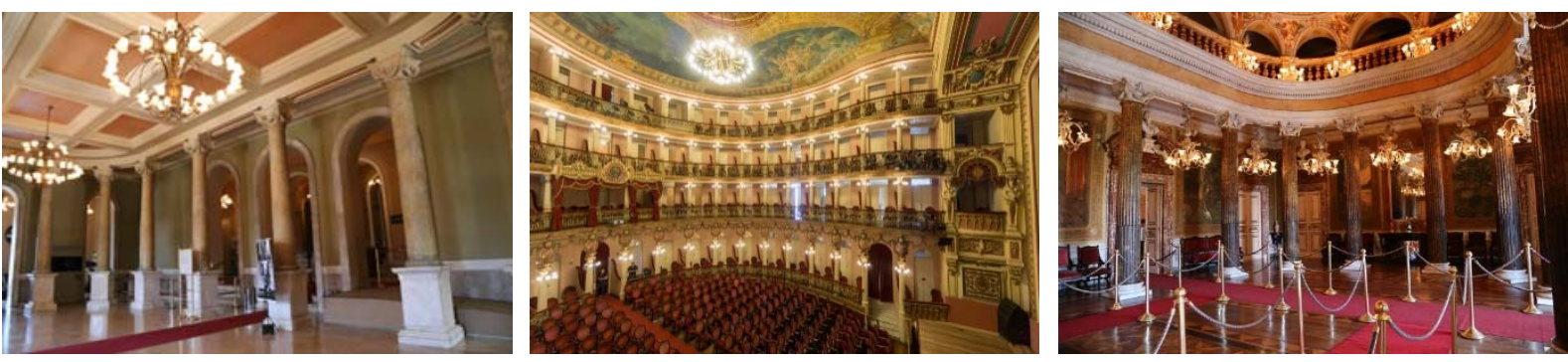

Figure 6: Amazonas Theater in 2019: a) Foyer; b) Concert Hall; c) Noble Hall. Filed in the Mário Ypiranga Library [19].

The Noble Hall also has 16 columns. Although supported by Carrara marble, the shaft is covered in plaster in order to imitate marble. The floor of the Noble Hall is the most original part of the Amazonas Theater, composed of 12 thousand pieces of wood placed with a technique called marquetry, which consists of not using nails or glue, making the woods stay in the perfect fit position. between the pieces. It is important to highlight that the Noble Hall decoration work, perfomed by the Italian painter Domenico de Angelis, extended for a few years after the official opening in 1896 (Figure 6c).
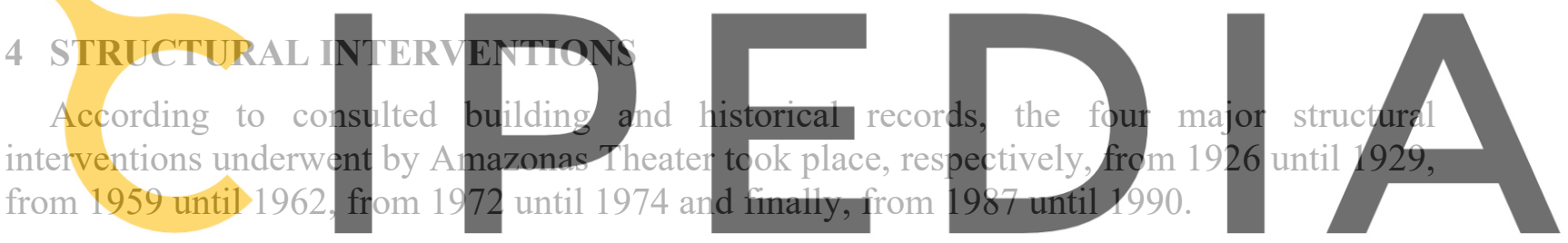

4.1 First structural intervention (1926-1929)

Register for free at https//Www.scipedia.com to download the version without the watermark

In the Ephigenio Ferreira de Sales administration (1926-1929), the building underwent internal changes (Figure 7a,b). The seven front cabinets of the second order were removed and a grandstand topped by a large stylized shell was built there (Figure 7b). There was also suppression of internal walls, which separated two longitudinal and continuous corridors to the friezes of the first order. The orchestra venue was expanded and stucco and painting works were done in the hall and corridors $[20,21,22]$. The Foyer was decorated with guaraná leaves and half pupunhas changing the original design of the Theater (Figure 7a). No record of changes in the Noble Hall during this renovation was found (Figure 7c).
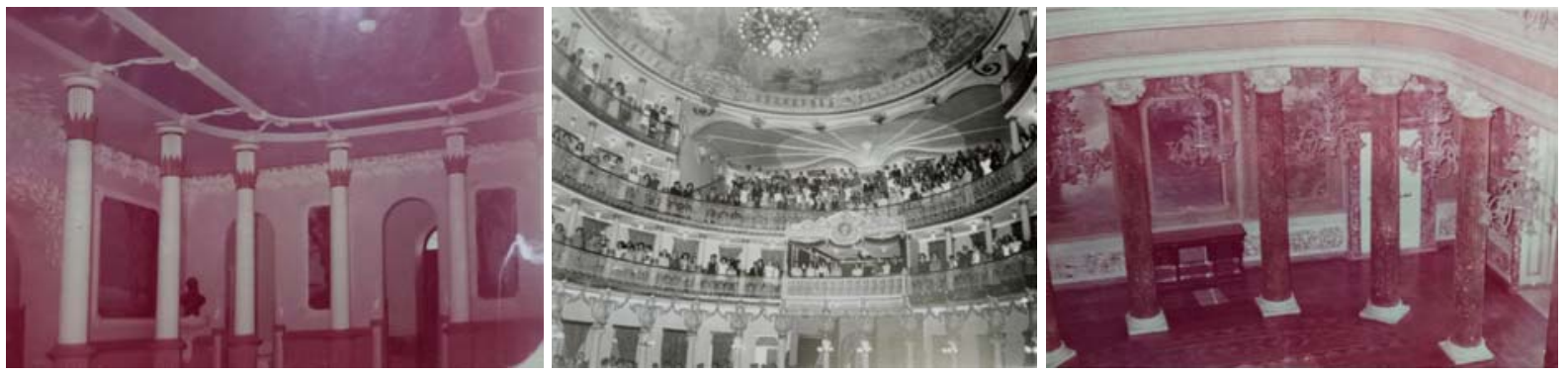

Figure 7: Amazonas Theater after renovation of 1926-1929: a) Foyer; b) Concert Hall; c) Noble Hall. Filed in the Mário Ypiranga Library [19]. 
Figure 8 shows the branches of guaraná behind the columns. The columns with capitals alluding to the Amazonian flora have half pupunhas and simple half flutes on the plinth [19].

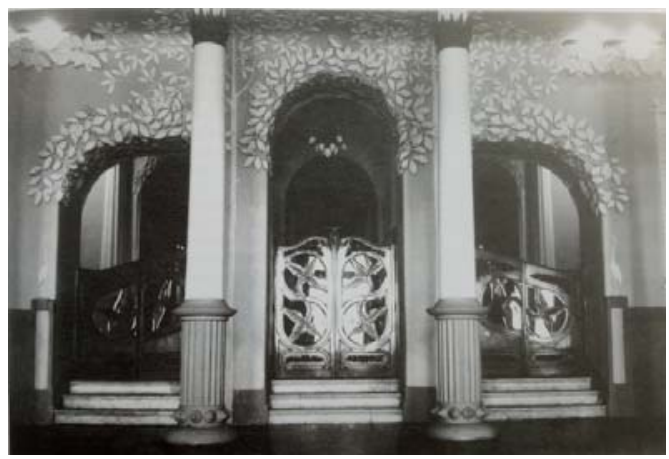

Figure 8: Foyer after renovation of 1926-1929. Filed in the Mário Ypiranga Library [19].

Amazonas Theater has been open for a long time, but since the 2nd World War it has remained almost closed for about 20 years.

\subsection{Second structural intervention (1959-1962)}

During the government of Gilberto Mestrinho de Medeiros Raposo (1959-1962), the theater underwent the second main structural intervention. Although the consulted historical records mention this restoration, details of the modifications, interventions and changes made in the

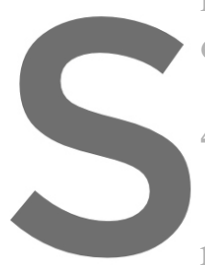
original structure of $t$

\subsection{Third structural intervention (1972-1974) \\ This restoration performed in the João Walter de Andrade} resumption of the original propositions of the
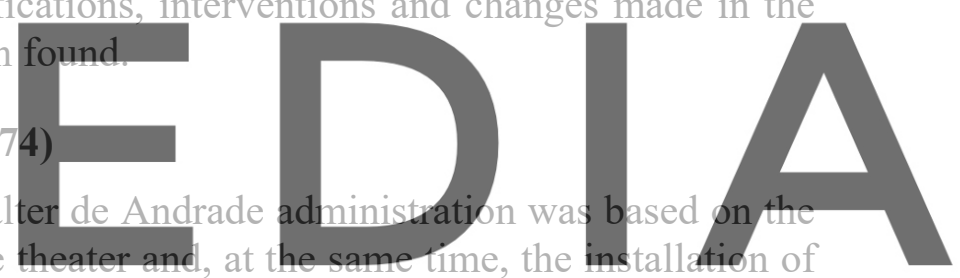

indispensable technical devices capable of giving it a compatible contemporaneity, without

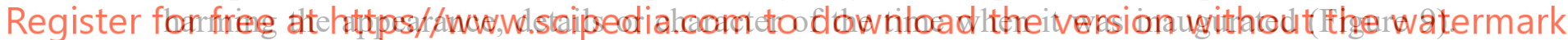

For this, a careful research work has been done to verify the details of its original design that have not been completed and, in addition, those that in subsequent renovations have been modified or misrepresented [23].

A thorough examination of the foundations, the structure in general, the steel structure in particular, the situation of the roof, the installations of light, power, water and sewage, the state of conservation of the frames and the ironmongery and the valuable existing paintings in theater. Some surveys were carried out to verify the foundations of the theater building and sufficient solidity and stability were found [23]

The steel structure that supports the roof was the object of special study in the face of deformations in the main element of the ridge. Structural stability analysis was performed and a report on the subject was presented suggesting corrective measures. As a result, reinforcements of steel profiled elements were added to the structure by electric welding. All steel frame paint was treated with a metallic brush and solvent, receiving new anti-oxide paint protection and two-coat finish. The wooden framework of the Noble Hall floor received, for reinforcement, a special steel structure, supported by the peristyle columns [23].

Still in terms of structural steel, it is worth mentioning that 120 tonnes of profiled steel, 
constituting the imported warp from Austria, were mounted on the stage box. To support this structure, another reinforced concrete was built, after being completely demolished the old wooden for improper and obstructive. As for the wood in the theater, there was a need to replace almost ninety percent of the structural elements, floors, ceilings and frames [23].

About two thousand and one hundred linear meters of wood beams were replaced. On these rebuilt frameworks, two thousand square meters of new floor were put in place, replacing the floor damaged by time and poor conservation. One thousand eight hundred square meters of wood lining have been replaced in the same way, preserving the shape, size, quality of the wood and the original look [23].

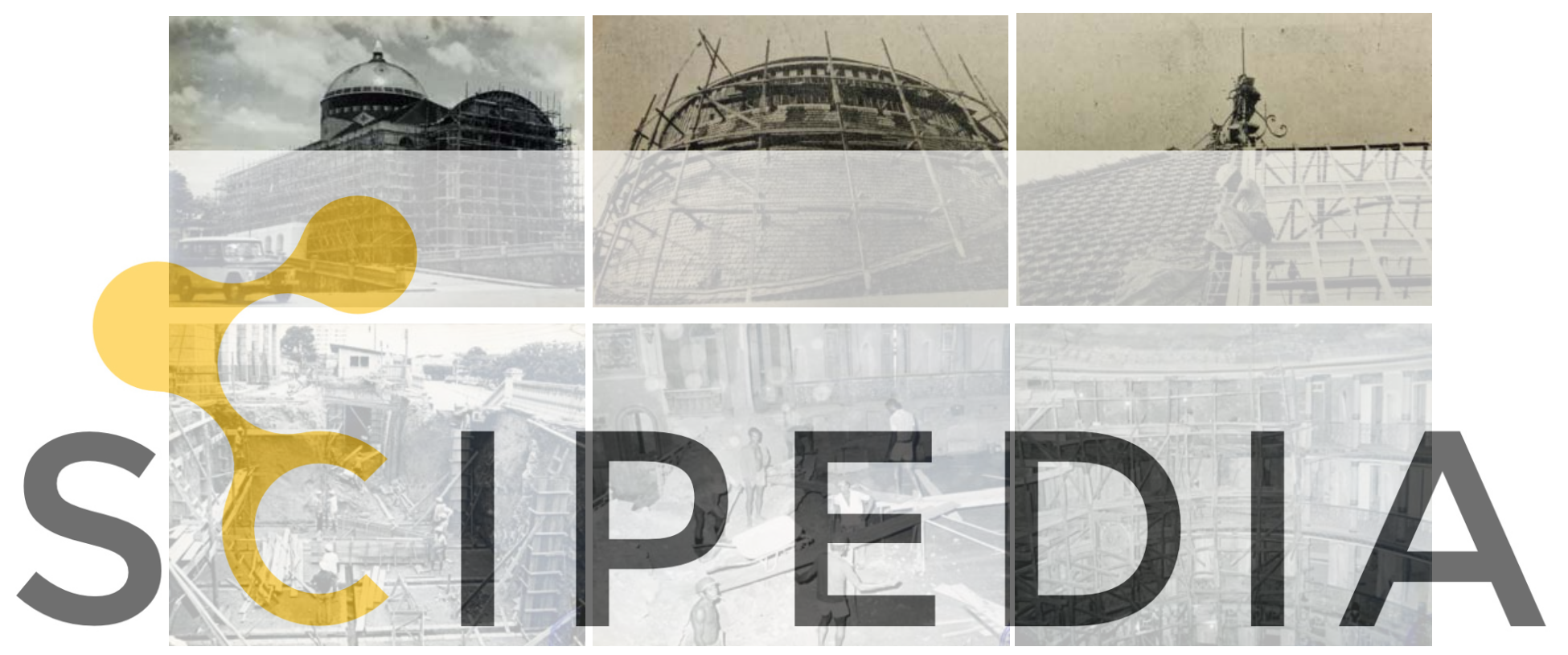

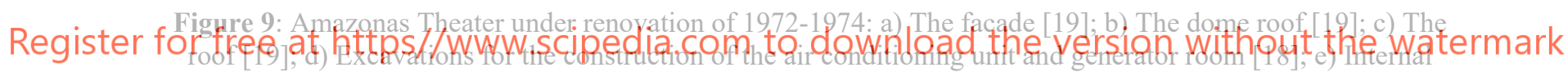
works of the Concert Hall [18]; f) Renovation of the friezes of the Concert Hall [18].

The frames, doors and windows, were removed, repaired and replaced their ironmongery, some of them had to be manufactured according to model. The two main side access stairs to the staterooms and friezes were demolished and replaced by reinforced concrete stairs and covered with Liós marble [23].

The lack of sanitary facilities required the construction of new units, thirty-two sets in the dressing room area and ten sets in the audience area. Taking into consideration the type and age of the theater building, one can get an idea of the difficulties in locating, building, finishing and installing the whole system, which is indispensable for the operation of a theater house with a larger population, a thousand people, including spectators, artists, musicians and technicians [23].

The stage box has been totally reformulated. All internal constructions were demolished and removed, taking advantage only of the outer walls. Then, with reinforced concrete structure, were built twenty dressing rooms, with capacity for seventy people, besides other service facilities, walkways, access, stairs, toilets, bar, involving a built area of nine hundred square meters and more than two thousand and five hundred square meters of brick masonry. A new 
wooden stage floor, including its structure, was built [23].

The original form and appearance of the concert hall has been restored and a gallery built in one of the renovations at the expense of the mutilation of the second and third cabins was demolished. This work restored the hall, restoring it to the classical, elegant conformation typical of the lyric theaters of the time. To this end, cast-iron railings and special columns were ordered to merge, completing, in the smallest detail, the boxes that had been suppressed [23].

\subsection{Fourth structural intervention (1987-1990)}

A decade after the last renovation, during the Amazonino Armando Mendes government (1987-1990), the theater underwent the last major restoration. The building's condition was precarious and a survey was conducted that pointed to the urgent need for further reform [18].

A long work of prospecting was carried out in all internal environments of the theater, as well as on the facades and walls. This technique was applied in places where supposedly there had been no previous interventions to observe the original. Several layers of paint and decorative elements were discovered [18].

The woods underwent several types of treatment. Thousands of liters of immunizers were consumed. Even so, about $40 \mathrm{~m}^{3}$ of wood totally damaged by the action of termites had to be removed. The new woods that were applied strictly followed the same specifications as the previous ones (Figure 10a).
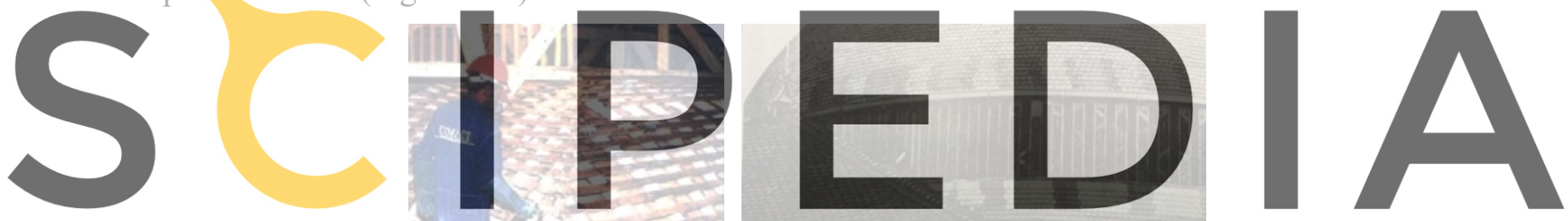

Register for free at https//www.scipedia.com to download the version without the watermark

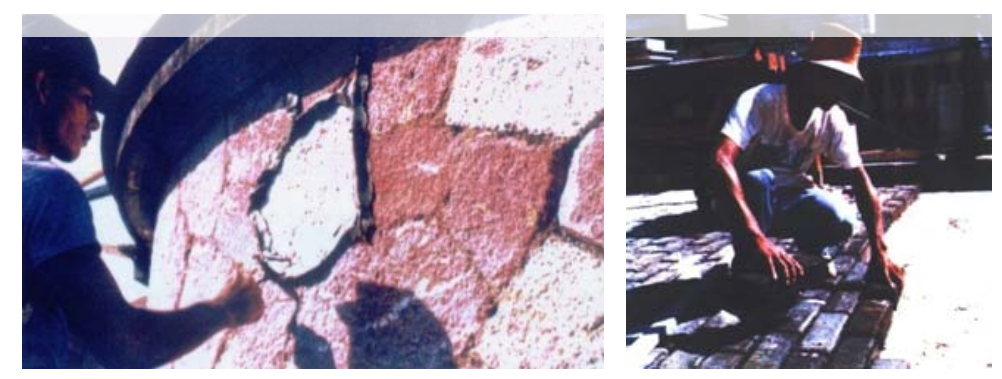

Figure 10: Amazonas Theater under renovation of 1987-1990: a) Treatment of the wooden structure of the Concert Hall plafond [18]; b) The dome roof [19]; c) Apparent surrounding wall restoration [18], d) The parallelepiped blocks restoration [18].

A reservoir with a capacity of forty thousand liters of water was built exclusively for fire fighting. The entire sewage and water installation system was replaced since the previous ones were in a high state of oxidation. In addition, a further 2,300 meters of piping were installed. To facilitate maintenance, the rainwater pipes that were embedded in the external walls gained a new direction and were connected to the network through external PVC rigid tubes [18]. 
For the feasibility of presenting any type of show, the theater was equipped with modern sound equipment. Over two hundred and seventy scenic projectors and other accessories have been restored. These are originally from England. The audience and the stage now have an efficient cooling system with the installation of a central. The dressing rooms also have cooling units. A new telephone installation system was developed and executed, serving the entire dressing room, bar, foyer and ticket office area. Closed circuit TV was installed covering the main space and interconnecting them through video monitors [18].

The drainage of the gardens was planned in such a way as not to allow water to seep into the apparent stone walls that delimit the external area of the Theater and was carried out in the four flowerbeds. In order to avoid infiltrations caused by the porosity of masonry and coverings, all terraces, slabs, substation, engine room, water tanks, cisterns, cornices and plateaus were waterproofed [18].

Part of the 36,000 enamelled ceramic tiles of the dome have been replaced. In previous renovations, original tiles were replaced and those that remained were given a coat of paint. The paint from thousands of original parts were removed while the non-original ones were completely replaced due to the very low quality standard (Figure 10b). The metal structure of the dome received careful repairs and the various points of oxidation were eliminated.

All the wooden ceilings in the circulation of the friezes were replaced since the ones that were there were placed without previous historical study. The other ceilings were overhauled and the damaged parts were replaced. The plaster-like ceiling of the frental cirquitation to the Noble Hall was completely rebult after reinforcing the structures. The dressing rooms circulations received a lowered ceiling made of easy-to-maintain aluminum material [18]. The wall surrounding the theater was completely painted and grafted with cernent and mortar imitating stone. As the research showed the wall was originally apparent, all the suspicious material found was removed and other stones with the same characteristics were cut

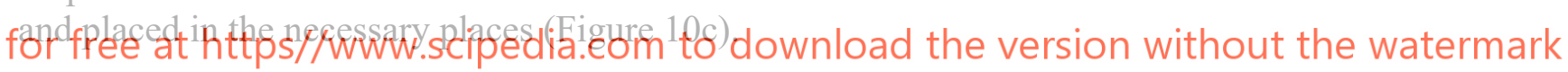

The woods on the stage floor that were previously in Louro-Preto and Jacareúba were completely replaced by Freijó. The other floors that bring wood such as Pinho de Riga, Acapú and Macacaúba, Amarelinho were scraped and sanded by hand. The white marble floors of the terraces, the noble balcony and the sills of the 1st floor have been replaced by Aurora Pérola marble. The Liós stone floors were polished and waxed [18].

The imported stones on the external sidewalks and staircases that had defects were reconstituted. The parallelepiped blocks of the external street were analyzed and 74 thousand pieces with the same characteristics and resistance as the originals were produced and laid (Figure 10d).

In the bathrooms and toilets, high-strength materials such as granite, marble and tiles were applied [18].

A total of 800 pieces of furniture including Concert Hall chairs and armchairs has been restored. Specialized restorers performed the restoration work on the theater's rich collection of 32 chandelier in Murano crystals, 166 bronze chandeliers equipped with 1,360 tulips, 2 curtains making a total of $308 \mathrm{~m}^{2}$, arch of proscenium, medallions, plafond of the Concert Hall with 204 $\mathrm{m}^{2}$, railings of the Concert Hall, fresco to the mask of the Concert Hall, plafond of the Noble 
Hall with $100 \mathrm{~m}^{2}$, parietal paintings of the Noble Hall, 6 cast iron statues, ceiling of the Noble Hall balcony, fresco to the mask of the room 37, 28 plans of the original drawing and the foyer columns

Finally, the structural wood embedded in the facades was totally attacked by termites. The classification and restoration of reusable wood was planned and a technical solution for structural recovery without causing architectural changes was studied [18].

During its renovations, the Amazon Theater had the colors imperial rose, bluish gray, and gray. Currently, Amazonas Theater is back to being imperial rose (Figure 11).
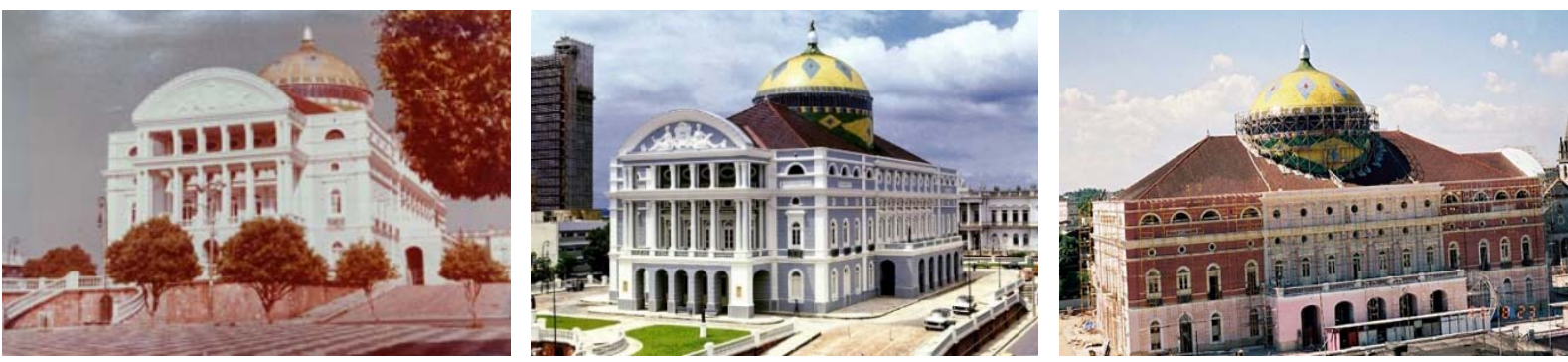

Figure 11: a) Before restoration of 1972-1974 painted in gray [19]; b) Under renovation of 1972-1974, painted in bluish gray [19]; c) Under renovation of 1987-1990, when it was painted in imperial rose, its current color

[19].

Recently, during a painting's scraping a deep gold layer was discovered. Gold was applied in a small amount, more or less in the same proportion that exists in the Noble Hall. Nowadays, almost 30 years after its last major restoration, Amazonas Theater retains much of its original decoration, architecture, paintings, furniture, floors and objects used 100 years ago. Besides that, a rigorous and permanent maintenance keep the original environment solid [18].

\section{CONCLUSIONS}

In this paper, a brief historical construction chronology of Amazonas Theater is presented. The structure and construction details as well as the main structural interventions performed during its 123 years are described. Considering all the challenges faced by a construction carried out in the middle of the largest tropical forest in the world, its construction presented advanced solutions for the time, highlighting the metallic structure of the roof including the dome that took two years to assemble. According to consulted building and historical records of the Theater, that took 17 years to open, its construction taking all this time mainly because of logistical issues, since practically all the materials used in its construction came from Europe.

Acknowledgements. The author would like to acknowledge the Escola Superior de Tecnologia, the Universidade do Estado do Amazonas, the Governo do Estado do Amazonas, the Secretaria de Cultura e Economia Criativa do Amazonas, the Gerência de Acervos Digitais, the Amazonas Theater, The Arquivo Público do Estado do Amazonas and the Memorial e Biblioteca Mário Ypiranga Monteiro for the support for this research. 


\section{REFERENCES}

[1] D.M. Durango. Manaus entre o passado e o presente. $1^{\text {st }}$ Edition, Mídia Ponto Comum, 2009.

[2] A. Caccavoni. Album Descriptivo Amazonico. Genova: F. Armanino, 1899.

[3] M.Y. Monteiro. Teatro Amazonas. $2^{\mathrm{a}}$ edição revista e aumentada. Manaus: Editora Valer. Governo do Estado do Amazonas, 2003. 686p.

[4] O.M. Mesquita. Manaus: história e arquitetura (1669-1915). $4^{\text {th }}$ Edition revisada e ampliada - Manaus: Editora Valer, 2019. 362 p.

[5] Annaes da Assembléia Legislativa do Amazonas. 1880-1881. Manáos: Typ. do Amazonas, 1881.

[6] A.J.Furtado. Exposição do presidente Alarico João Furtado, 7 de março de 1882. Manáos: Typ. do Amazonas, 1882.

[7] J.L.C. Paranaguá. Relatório do Presidente em 25 de março de 1883. Manáos: Typ. do Amazonas, 1883.

[8] J.L. Paranaguá. Relatório do Presidente em 16 de fevereiro de 1884. Manáos: Typ. do Amazonas, 1884.

[9] J.L.S. Coelho. Relatório do diretor da Repartição de Obras Públicas em 8 de julho de 1884. Manáos: Typ. do Amazonas, 1884.

[10] J.J. Ferreira Júnior. Fala do presidente da Provincia em 21 de setembro de 1885. Manáos: Typ. Jornal do Amazonas, 1886.

[11] L.B.Bitancourt. Relatório do diretor interino da Repartição de Obras Públicas em 10 de fevereiro de 1886. Manáos: Typ. Jornal do Amazonas, 1886.

[12] E.G. Ribeiro. Mensagem do governador em 10 de julho de 1893. Manáos: Typ. do Diário Official, 1893.

[13] E.G. Ribeiro. Mensagem do governador em 10 de julho de 1894 . Manáos: Imprensa Official, 1894.

[14] E.G. Ribeiro. Mensagem do governador em 1 de março de 1896. Manáos: Typ. do Diário Official, 1896.

[15] F.P. Ferreira. Mensagem do governador em 4 de março de 1897. Manáos: Typ. do Diário Official, 1897.

[16] Governo do Estado do Amazonas. Secretaria de Cultura e Economia Criativa do Amazonas. Gerência de Acervos Digitais.

[17] I.B. Filho. Acervo pessoal. Manaus: 4 de junho de 2019.

[18] Governo do Estado do Amazonas. Secretaria de Cultura e Economia Criativa do Amazonas. Museu do Teatro Amazonas.

[19] Governo do Estado do Amazonas. Secretaria de Cultura e Economia Criativa do Amazonas. Memorial e Biblioteca Mário Ypiranga Monteiro.

[20] E. F. Salles. Mensagem do governador do Amazonas em 21 de dezembro de 1927. Manáos: Typ. da Imprensa Publica. 1927.

[21] E. F. Salles. Mensagem do governador do Amazonas. Manáos. 1928.

[22] E. F. Salles. Mensagem do governador do Amazonas. Manáos. 1929.

[23] C.P. Valladares. Restauração e recuperação do Teatro Amazonas. Governo do Estado do Amazonas, 1974. 